\title{
The Study of Situation of Employment of humanities graduates of Payame Noor University in the Labor Market (Case Study: Sanandaj University)
}

\author{
Anvar Shahmohammadi \\ Academic Member, Humanities Department, Payame Noor University, \\ 19395-4697 Tehran, I.R. of Iran
}

Tel: 00989189704966, Fox: 00988717270319

Yaaghob Ahmadi (PHD in Sociology)

Assistant Professor, Sociology Department

Payame Noor University 19395-4697 Tehran, I.R. of Iran

Accepted: November 20, 2011 Published: January 02, 2012

Doi:10.5296/ijld.v2i1.1219ＵRL: http://dx.doi.org/10.5296/ijld.v2i1.1219

\begin{abstract}
Payame Noor University as one of the universities of Iran has responsibility of training of specialists and experts labor forces for society in different disciplines. Performed studies show that the most important in the success of graduates in finding the appropriate work is the proportionate between processes and materials of educational in different courses in universities with skills and abilities needed in labor market. The goal of this study is measure of the employment of human sciences graduates in the job market. The methodology of this article of is survey. The population of all graduate students in the Humanities of Payame Noor in 2010-2011 in Sanandaj is 850 people. Appropriate sample sizes in this study were 265 and final participants selected through systematic random sampling method. Descriptive findings indicate that 69.8 percent of respondents are women. 69/4\% of them are in the age group of 25-23 years. 56/6 percent has the mean 14 to 15/99 And 57/4 percent of respondents are unemployed. Analytical Results show that there is significance relationship between Age, Course and grade average with employment of human sciences graduates. Results also show that sex has a high impact on employment of graduates.
\end{abstract}


Key Word: $\quad$ University, Graduates, Employment, humanities, expert

\section{Introduction}

One of the most important missions of higher education is training the Efficient and committed forces that have the major role in development of any country. Therefore, job creation and the use of its services, should be as the most important engagement of the higher education system till with use of this unmatched and decisive capital, it could lead the country to increasing development. Employment of graduates of higher education is one of the most important indicators for the evaluation of its effective (Ahanchyan, 2003).

Today in Iran, the problem of employment of graduates and their skills has became one of the central worries of State, Universities, industrial planners and policy makers. In fact, for awareness of the capabilities of training provided, skills needed for employment and educational and research programs, universities have need to assessment of situation of graduates and their employment in labor market (Mehr Ali Zadeh and Armen 2007).

The employment of graduates of universities and centers of higher education depends on have some abilities and features, which a part of those should be, trained at universities and centers of higher education. So, Universities and centers of higher education undertake some missions such as expanding knowledge, training the specialist forces, develop the technology, innovation and creativity. Hence, now, most of scientists believe that sustainable development is acquired by only application of knowledge and advanced technology. As Hamerlinck and Emery (2006) point out, now, an expanded dedication to entrepreneurship can open up economic opportunities while simultaneously furthering the educational missions of colleges and universities by promoting a scholarship of relevance. Today higher education plays an increasingly active role in many local and regional economies.

The situation of graduate's employment has been determined by some features and social factors. As Bracey (2006) argue, While he recognizes the civil rights issue in the debate--everyone should have the opportunity to develop the skills to land a high-paying job--the law of supply and demand dictates that more high-skilled workers would result in lower wages and higher unemployment for all. He also maintains that most new jobs are in the low-paying service sector, and that producing many more college graduates would make many 
people overqualified for the available work. Instead, he says, the reason that young workers cannot find work is precisely because they are young and are not perceived as having the basic skills or work attitudes necessary to succeed. In surveys, strong academic performance came relatively low on the list of most desirable traits in a worker, demonstrating that test scores and other indicators are not necessarily a good measure of an individual's employability.

Elliot and et.al (2004) by the study about unemployment rates of graduates in different fields on East of England conclude that there is meaningful relationship between the level of employment and educational courses of graduates. Green House (2003) and Cartmell and Qaton (2004) researchs also showed that Individual agents has effect on the employment rate of people. They concluded that there is significant relationship between gender and age of employment.

In another study in England by Brynin (2002), results showed that the rates of female graduates is more that male and he argued that this is for the promotional aspects and more responsibility of women in the work environment. Researches of Horn and Zahn (2002) show that only 20 percent of the graduate in1997 (entry 1992) All graduates of Business, Engineering and Computer Courses have been working full time; in contrast, about 79 percent of Art social sciences graduates were employed.

In Iran, there has been done some study about employment, especially graduates employment and unemployment. For example: results of Rezvani et.al research (1389) shows that factors such as Gender and academic discipline has been effected on the employment rate of individuals. In another study, Salehi (1385) shows that factors such as knowledge and acquired information in university, academic skills and Courses are effective in employment. Results also show that age, gender and educational average.

PayameNoor University as the biggest university in Iran that has an Educational flexibility system has created for expanding of knowledge in all of the regions of Iran. Univestiy of Payamenoor University of Sanandaj as one of these centers been established in recent years and in this period, it have graduated many students in many courses. Thus, awareness of the situation graduates in the field of employment and effective factor of it, is essential for future academic programs. So, this article is aim to answer this question: How is the employment situation of graduates in the labor market? 


\section{Theoretical Framework:}

Human capital competencies, understood as those talents, skills and capabilities of higher education graduates that contribute to multi-factor productivity gains, are perceived as a key element for sustainable economic growth and development in the globalize economy (Sianesi \& Van Reenen, 2003). Increasingly, policy makers are focusing on the importance of competencies with a focus on: linkages between productivity; the demand for competencies and globalization; the need to take advantage of new technologies and problems of labor market transition among young adults (Bradley \& Nguyen, 2004). High levels of education, defined conventionally as more years of education, are not enough; modern complex societies are demanding specific competencies. Individuals can obtain these competencies through experience, training, or more informal means. Formal learning may increase or decrease differences in the abilities and levels of competence of individuals (Tyler, Murnane \& Willett, 2003).

The introduction of new technologies changes the nature of work, and affects the value and content of the competencies required (Mariachristina et al., 2003). Some competencies accumulated by workers will become less relevant, while others will become crucial. This is standard thinking about technological change and "skills" obsolescence and is the logic behind vintage human capital (De Grip, Van Loo \& Mayhew, 2002). Evidence of growing wage gaps between more- and less-skilled individuals has drawn attention to the emergence in economies of a skill-intensity bias in labor demand (Acemoglu, 1998). Therefore, technological change generates a mismatch between the supply of and demand for competencies, and wage inequality results from the inability of the supply side to keep up with demand requirements (Witte \& Kalleberg, 1995).

These changes have raised concerns about the accuracy of the match between higher education and employment of graduates (Hoogveld, Paas, \& Jochems, 2005). Among these concerns, two have attracted the attention of researchers. The first is the identification of those competencies that are more relevant to graduates' professional success (Robinson, Sparrow, Clegg, \& Birdi, 2005). The second is whether and how these competencies are generated (or 
may be promoted better) by higher education systems (Yang, You \& Chen, 2005). Providing a clear answer to these questions is far from straightforward due to the heterogeneity of the productivity-enhancing characteristics of graduates.

Analysis of the matching between job level and level of education based on the notion of an adequate match as a one-to-one relation is vulnerable to the criticism that it involves a very rigid view of optimal allocation (Barro \& Loewenstein, 1985). In this sense, job level is a variable that measures the complexity of a job, often expressed as the required ability level of a worker, and sometimes as required education (Hartog, 2001). It suggests the existence, for each level of education, of an optimum job level and the implication that allocation to any other job level is necessarily suboptimal, particularly, with respect to under-utilization. If this match is not optimal, additional learning through training and work experience will be needed to improve or adjust the initial competencies acquired during education. Indeed, the importance of on-the-job training for improving competencies has long been emphasized (Mincer, 1974) and there have been many debates about its impact on productivity and wages (Raaum \& Torp, 2002).

According to those models, individuals working in jobs for which a higher level of education than they actually have, is required (under-education) will often earn more than individuals with the same level of education working in jobs for which their level of education is appropriate, but less than individuals with the level of education that is actually required (Hartog \& Oosterbeek, 1988). Conversely, individuals working in jobs for which a lower level of education than they have is required (over-education) will often earn less than individuals with the same level of education working in jobs for which the level is appropriate (adequate education), but more than individuals working in an equivalent job with the level of education actually required. That is, the wage effects of over-education are usually stronger than the wage effects of under-education.

Hartog (1988) shows that the probability of achieving a higher job level is highest for individuals whose earnings gain across job level is greatest. The higher the job level, the higher the compensation demanded by the individual for further increasing complexity. Similarly, at higher wage levels, individuals are less reluctant to take on more demanding jobs. Other 
authors (Robie, Ryan, Schmieder, Parra, \& Smith, 1998) suggested a positive relationship between job level and job satisfaction. Higher-level jobs tend to be more complex, provide better working conditions, pay, promotion prospects and supervision and carry greater autonomy and responsibility (Cranny, Smith \& Stone, 1992). Additionally, economists have made much progress in understanding that monetary incentives are important, but that there are also powerful non-monetary motives that provide incentives for individuals to perform specific tasks (Fehr \& Falk, 2002; Igalens \& Roussel, 1999). Jobs that are inherently satisfying provide an intrinsic reward to those performing them.

A number of economic and other social science studies on the subjective utility of working have shown that higher levels of education are unambiguously associated with higher levels of satisfaction (Ross \& Van Willingen, 1997). As Hartog (2000) pointed out educational mismatches can be explained by differences in the shares of complex jobs and skilled workers. Moreover, related Theories with the education and labor market generally can be divided into five groups: functional- technical theory; human capital theory; Critical theory, economic theory and revised version of Weber's theory.

- Functional- technical theory believes that technology lead to increase of the skill level of jobs

- Human capital theory is based on the classical theory of $y=$ (K.L.T.Q.U).

- Critical theory their views are offered in two axes: the reproduction of social and economic equality through the education system and the degree of integration between Needs of employers and capitalists, and theTraining.

A revised view that Weber was reviewed by Brown and Scase, a new aspect of the relationship between education and labor market studies have Drawing from their creative and practical aspects of work organization and production aspects of the occupant's personality.

As Knight and York have expressed, the employment of university graduates related by a combination of personal abilities, skills and understanding of diversity and dominance of their field.York believe that there is underestimate, traditionally, about personal skills and capabilities in situation of employment, but these skills are very effective in their job (Knight, 2001 yorke, 2001). 


\section{Background research}

\section{External Studies:}

Ivan eIyich (1981) in their study as the relationship between formal education while studying the employment of university graduates showed that 42 percent of graduates are employed and 14 percent among the unemployed. A study in 1997 of England by Zahn and Horn (2001) shows that among the graduates (entry 1992), only 20 percent were unemployed. All graduate business courses in engineering and computer science work and about 90 percent of them have worked. However, percent of employment in the human sciences and art courses is lower ; that's about 79 percent. Another study conducted in England (Bryanin, 2002) shows that the employment of female graduates has been more than the boys, it is considered because of the promotional aspects and responsibility of women in the work environment.

In another study by Elliot et.al (2004), employment and unemployment rates of Graduates were survey in the East of England in different fields. Results showed that there was the relationship between academic disciplines and absorbing in the labor market

\section{Internal studies:}

Internal surveys show that the number of graduates in employment has been described. For example: Mir Hadi (1380) in their study examining the employment of graduates with skills in business associate Knowledge of the jobs in the province in 1379 showed that the relationship between gender and type of jobs are graduates.

Poor Haghighi results and Khademi (1383) suggests that more than 95 percent of graduates in management Education that have been absorbed into the labor market More than 90 percent of the employed in education and very few in the organization other jobs or are unemployed.

Nik khah findings (1383) showed an average rate of employment of graduates of technical and professional education in the Kurdish city of about 25Percent of 24 percent more graduates in education and 51 percent unemployed, housewives and soldiers have been. Mohammad-Zadeh (1385) showed that 40 percent of graduates are unemployed agricultural universities of applied science. Research results Salehi Omran (1385) shows that factors such as knowledge and information in the field of Job fit with academic courses and skills acquired during the course of employment is effective. The study also shows between gender and average age of students 
graduating with their employment relationship exists. Rezvani et al study (1389) shows that factors such as gender and academic discipline in the employment rate of people have been effective

\section{Methods}

\section{Data and Sample}

This study is a descriptive survey. The society is all of the graduate in humanities course of Payam Noor University in Sanandaj, 89-90 years, with a population of 850 people. The responders of the study were 275 citizens. But because of some damaged Questionnaires, about 265 Questionnaires was analyzed:

$$
\begin{aligned}
& N=850 \\
& t=1.96 \\
& p=0.5 \\
& q=0.5 \\
& d=0.05
\end{aligned}
$$

$$
n=\frac{N\left(t^{2} p q\right)}{N d^{2}+\left(t^{2} p q\right)} \cong 275
$$

On this basis, units of graduate study and research within the first six months of the year is 1390

Ask one of the methods described in the analysis of descriptive statistics such as the Central and Disperesion Indexes and bonds on the assumption of nominal variables with respect to the Test Chi Esquere statistic for the independence of individual variables, or inconsistent with the employment variable is used Test 
Table 1: Demographic characteristics of respondents

\begin{tabular}{|c|c|c|}
\hline Variable & Dimension & percent \\
\hline & Man & $30 / 8$ \\
\hline Sex & Woman & 69.2 \\
\hline \multirow{2}{*}{ Employment Status } & Working & $42 / 6$ \\
\hline & Unemployed & $57 / 4$ \\
\hline \multirow{4}{*}{ age } & $22-20$ & $3 / 4$ \\
\hline & $25-23$ & $20 / 8$ \\
\hline & $28-26$ & $69 / 4$ \\
\hline & $31-29$ & $4 / 6$ \\
\hline \multirow{9}{*}{ Lists } & Psychology & $16 / 2$ \\
\hline & History & 3 \\
\hline & Law & $10 / 6$ \\
\hline & Social Sciences & $12 / 8$ \\
\hline & Accounting & 17 \\
\hline & Administration & $18 / 1$ \\
\hline & Literature & $9 / 8$ \\
\hline & Geography & 3 \\
\hline & Educational Sciences & $9 / 4$ \\
\hline
\end{tabular}




\section{Results}

In this section, results of research were indicated based on two dimensions, descriptive and explanation results:

\section{Descriptive and Explanation Results}

According to the descriptive analysis of data shows that about 69.2 percent of student is female and $30 / 8$ percent is male.

$17 \%$ of students have graduated from a in Accountancy field and for another fields of such as Psychology, Social Sciences, Public Management, Educational Sciences and Geography, history, literature, business management this percent is, respectivlty $16.2 ; 12.8 ; 11.7 ; 10.6 ; 9.8$; 9.4; 6.4 and 3. 69.4 Percent of graduate Students han been between ages of 23 to 25 years old, While this percentage for the age group of 26 to 28 years is $20.8 \%$.

Age groups of 20 to 22 years is 6.4 percent and 3.4 percent is for 29 to 31 . The Average of 50.9 percent of samples has been from 14 to 15.99. This perecentage for average of 12 to 13.99 , 35.5; and for 16 to 17.99 and 18 to 19.99 respectiely is 12.8 and only 0.8 percent. 57.45 percent of graduates has been unemployed and 42.6 percent of them have been able to be absorbed in the labor market. 
Table 2: Chi Square test results according to gender

\begin{tabular}{|c|c|c|c|c|}
\hline \multirow{2}{*}{ Total } & \multicolumn{3}{|c|}{ Employment Status } & \multirow{2}{*}{ Sex } \\
\cline { 2 - 4 } & Unemployed & Working & \multirow{2}{*}{ Man } \\
\hline 80 & 38 & 42 & Views & \multirow{2}{*}{ Woman } \\
\hline 185 & 45.9 & 34.1 & Expected & \multirow{2}{*}{ Views } \\
\hline 185.0 & 114 & 71 & Expected & Total \\
\hline 256 & 106.1 & 78.9 & 113 & Views \\
\hline 256.0 & 152.0 & 113.0 & Expected & \\
\hline
\end{tabular}

Sig $=0.033 \quad \mathrm{p}<0.05$

$\mathrm{df}=1$

$$
\mathrm{X}^{2}=4.554
$$

Table 3 : Chi Square test results according to age group

\begin{tabular}{|c|c|c|c|c|}
\hline \multirow[t]{2}{*}{ Total } & \multicolumn{3}{|c|}{ Employment Status } & \multirow[t]{2}{*}{ Age group } \\
\hline & Unemployed & Working & & \\
\hline 9 & 1 & 8 & Views & \multirow{2}{*}{$29-31$} \\
\hline 9.0 & 5.2 & 3.8 & Expected & \\
\hline 55 & 26 & 29 & Views & \multirow{2}{*}{$26-28$} \\
\hline 55.0 & 31.5 & 23.5 & Expected & \\
\hline 184 & 111 & 73 & Views & \multirow{2}{*}{$23-25$} \\
\hline 184.0 & 105.5 & 78.5 & Expected & \\
\hline 17 & 14 & 3 & Views & \multirow{2}{*}{$20-22$} \\
\hline \multirow[t]{3}{*}{17.0} & 9.8 & 7.2 & Expected & \\
\hline & & & Views & \multirow{2}{*}{ Total } \\
\hline & & & Expected & \\
\hline $\begin{array}{l}\text { Sig }=0.02 \\
X^{2}=15.162\end{array}$ & & & 0.05 & $\mathrm{df}=$ \\
\hline
\end{tabular}


Table 4: Chi Square test results mean in terms of graduation

\begin{tabular}{|c|c|c|c|c|}
\hline \multirow{2}{*}{ Total } & \multicolumn{3}{|c|}{ Employment Status } & \multirow[t]{2}{*}{ Average graduate } \\
\hline & Unemployed & Working & & \\
\hline 2 & 0 & 2 & Views & \multirow{2}{*}{$18-19 / 99$} \\
\hline 2.0 & 1.1 & 0.9 & Expected & \\
\hline 34 & 11 & 23 & Views & \multirow{2}{*}{$16-17 / 99$} \\
\hline 34.0 & 19.5 & 14.5 & Expected & \\
\hline 135 & 71 & 64 & Views & \multirow{2}{*}{$14-15 / 99$} \\
\hline 135.0 & 77.4 & 57.6 & Expected & \\
\hline 94 & 70 & 24 & Views & \multirow{2}{*}{$12-13 / 99$} \\
\hline \multirow[t]{3}{*}{94.0} & 53.9 & 40.1 & Expected & \\
\hline & & & Views & \multirow{2}{*}{ Total } \\
\hline & & & Expected & \\
\hline Sig $=0.000$ & & & 0.05 & $\mathrm{df}=3$ \\
\hline
\end{tabular}

$\mathrm{x} 2=23.887$

Table 5: Chi Square test results in terms of graduate courses

\begin{tabular}{|c|c|c|c|c|}
\hline \multirow{2}{*}{ Total } & \multicolumn{3}{|c|}{ Employment Status } & \multirow{2}{*}{ field } \\
\cline { 2 - 4 } & Unemployed & Working & \multirow{2}{*}{ Psychology } \\
\cline { 2 - 4 } 43 & 18 & 25 & Views & \\
\hline 43.0 & 24.7 & 18.3 & Expected & \multirow{2}{*}{ History } \\
\hline 8 & 3 & 5 & Views & \multirow{2}{*}{ Law } \\
\hline 8.0 & 4.6 & 3.4 & Views & \multirow{2}{*}{ Social Sciences } \\
\hline 28 & 17 & 11 & Views & \\
\hline 28.0 & 16.1 & 11.9 & Expected & \multirow{2}{*}{ Accounting } \\
\hline 34 & 20 & 14 & Views & \\
\hline 34.0 & 19.5 & 14.5 & Expected & \\
\hline 45 & 17 & 19.2 & \\
\hline 45.0 & 25.8 & &
\end{tabular}




\begin{tabular}{|c|c|c|l|l|}
\hline 17 & 11 & 6 & \multicolumn{1}{|c|}{ Views } & Business \\
\hline 17.0 & 9.8 & 7.2 & Expected & \\
\hline 31 & 16 & 15 & Views & Public \\
\hline 31.0 & 17.8 & 13.2 & Expected & Administration \\
\hline 26 & 23 & 3 & Views & Literature \\
\hline 26.0 & 14.9 & 11.1 & Expected & \\
\hline 8 & 7 & 1 & Views & Geography \\
\hline 8.0 & 4.6 & 3.4 & Expected & \\
\hline 25 & 20 & 5 & Views & Educational \\
\hline 25.0 & 14.3 & 10.7 & Expected & Sciences \\
\hline 256 & 152 & 113 & Views & Total \\
\hline 256.0 & 152.0 & 113.0 & Expected & \\
\hline
\end{tabular}

Sig $=0.000$

$\mathrm{p}<0.05$

$\mathrm{df}=9$

$\mathrm{x} 2=32.014$

\section{Conclusion}

This study has been done for determination of the employment rate of graduates in the Humanities University of Payame Noor of Sanandaj. Findings indicate that $57.4 \%$ of the cases have not yet absorbed into the labor market and only $42.6 \%$ could be absorbed in the labor market.

The results of this study' also show that Gender has effect on situation of graduates that means male could be more absorption in labor market that female. This finding confirms that the result of Rezvani and others (2010) study that shows that male students have been more successful than female students in finding jobs. Therefore, the employment of them is in higher than from women. Moreover, this results is confirm Mirhadi (2000) study as the employment rate of graduates Associate in Kardansh skills in Isfahan showed that there was relationship between e gender of respondents and situations their employment..

Another examined Variable in this study was Course of graduates and results shows that there is meaningful relationship between Educational Field of graduates and their employment that this is not match with Rezvani et al result (2010).

The third hypothesis of this study was about relation between Age and employment of graduates. The results show that there is meaningful relationship between Age and employment of graduates. This finding is consistent with results Green House (2003) Kartmel 
and Gaton (2004). In their studies, they emphasis that factors such as age and marital status has meaningful effect on employment status of individuals.

Overall, the proportion of unemployed workers shows that there is fragile situation in employment of graduates. Also mentioned above, a significant percentage of graduates have not yet absorbed to work and as it is clear, most of them employ by State organizations. Therefore, any change in government economic and employment policy will be effective on the situation of employment of graduates. On the other hand, the shortcomings such as lack of attention of authorities to Employment of graduates has been led to less Entrepreneurship and self-employment of Graduate and this in itself will lead to worse situation. 


\section{References}

Acemoglu, D. (1998). Why do technologies complement skills? Directed technical change and wage inequality. Quarterly Journal of Economics, 113, 1055-1089.

AHanchyan MR (1382) Productivity and the employment of graduates of higher education presented in the first national conference on employment and higher education system

Allen, J., \& Van der Velden, R. (2001). Educational mismatches versus skill mismatches: Effects on wages, job satisfaction and on-the-job search. Oxford Economic Papers, 53(3), 434-452.

Ashton, D. N and Green, F. (1996) Education, trainingand the global economy. Edward Elgar. Cheltenham, UK, Brookfield, US.

Becker, G. S. (1980). Human capital, a theoretical and empirical analysis with special reference to education. Chicago/London: The University of Chicago Press.

Belfield, C. R., Bullock, A. D., \& Fielding, A. (1999). Graduates' views on the contribution of their higher education to their general development: A retrospective evaluation for the United Kingdom. Research in Higher Education, 40(4), 409-438.

Bracey, G. W. (2006). Students do not need high-level skills in today's job market. Education Digest: Essential Readings Condensed for Quick Review. Vol 72, Issue 4. P: 24- 28.

Brown, P. and Lauder, H. (1997) Education, globalisation and economic development. In: Halsey, A, H. Lauder, H. Brown, P, and Stuart Wells, A. eds. Education, culture, economy and society. pp.172-193, Oxford, Oxford University Press.

Brown, P. and Scase, R. (1994) Higher Education and Corporate Realities, UCL Press, London

Carnoy, M. and Levien, H..M. (1985) Schooling and work in the democratic state. Stanford University Press. Paulo. California

Clark, A. E., \& Oswald, A. J. (1996). Satisfaction and comparison income. Journal of Public Economics, 61, 359-381.

Cohn, E. (1992). The impact of surplus schooling on earnings: Comment. Journal of Human Resources, 27(4), 679-682.

Crites. J. O (1969). Vocational Psychology. New York. Mac Graw Hill Book Company.

De la Fuente, A. \& Ciccone, A. (2003). Human Capital in a Global and Knowledge-based Economy, European Comission, DG. For Employment and Social Affairs, Luxembourg.

Dearing, R. (1997) Higher Education in the Learning Society. Report of the National Committee of Inquiry into Higher Education. HMSO, Norwich.

Dunne, E.J. \& Rawlins, M. (2000) Bridging the gap between industry and higher education: training academics to promote student teamwork. Innovations in Education and Training international, 37 (4) 361-371

Dweck, C. (1999) Self-theories: their role in motivation, personality and development. Psychology Press, Philadelphia.the Orange Free State, Bloemfontein.

Hamerlinck, J. \& Emery, M. (2006), Entrepreneurship: A unique opportunity for higher education. NCRCRD Policy Briefs. North Central Regional Center for Rural Development.p $1-4$.

Hartog, J. (2000). Over-education and Earnings: Where are we, where should we go? Economics of Education Review, 19(2), 131-147. 


\section{MIMacrothink}

International Journal of Learning \& Development

ISSN 2164-4063

2012, Vol. 2, No. 1

Hartog, J., \& Oosterbeek, H. (1988). Education, allocation and earnings in the Netherlands: Overschooling? Economics of Education Review, 7(2), 185-194

Harvey, L. (1997) Graduates' work: organisational change and student attributes. Centre for Research into Quality, University of Birmingham.

Hughes, D.and Lauder, H. (1991) Human capital theory and the wastage of talent, New Zealand Journal of Educational Studies, 24 (1), pp.1-15.

Kellermann, P. (2007). Acquired and required competencies of graduates. In U. Teichler (Ed.), Careers of university graduates: Views and experiences in comparative perspectives. Dordrecht: Kluwer (in press).

Knight, P. \& Yorke, M. (2001) Employability through the curriculum. Skills Plus Project Report. Learning and Teaching Support Network (LTSN) (2002) Generic Centre: Programme for employability.

S. Kaveh (1386) identify a suitable career choice factors in selecting a job Study Publications: Tehran government.

Saidi. Mahmoud Rezvani. Zadeh MH. M. Baghgoly. Hossain (2010) the fate of graduate employment Mashhad University Faculty of Education and Psychology. Article. Journal of Educational Psychology, Ferdousi University of Mashhad XI. 2. Mashhad.

Salehi Omran. Ebrahim (2006) Female graduates' employment status. A case study. Research Planning in Higher Education.

Shafi Abad. Abdulla (1996)Career academic guidance. Payam Noor University Press, fourth edition. Tehran.

Shafi Abad. Abdulla (2010) Career counseling and professional guidance. Publications: growth. Published in the eighteenth

Sianesi, B., \& Van Reenan, J. (2003). The returns to education: Macroeconomics. The Journal of Economic Surveys, 17(2), 157-200.

Teichler, U., \& Kehm, B. (1995). Towards a new understanding of the relationships between higher education and employment. European Journal of Education, 30(2), 115-132.

Turkish Nooshin (1388) Management jobs. Monthly social. Economic. Cultural. No. 108. Tehran

Yorke, M. (2001) Employability in the first cycle higher education. A working paper for the 'Skills plus' Project. Liverpool John Moores University. 